\title{
COMPARISON OF BATCH AND NOVEL CONTINUOUS ELECTROCOAGULATION PROCESSES IN THE TREATMENT OF PAINT INDUSTRY WASH WATER
}

\author{
Kyösti Rajaniemi ${ }^{1}$, Mari Raulio ${ }^{2}$, Sari Tuomikoski ${ }^{1}$, Ulla Lassi ${ }^{1}$ \\ ${ }^{1}$ University of Oulu, Faculty of Technology, Research unit of Sustainable Chemistry, Erkki \\ Koiso-Kanttilankatu 1 (P.O.Box 4300), FI-90014 University of Oulu, Finland \\ ${ }^{2}$ Tikkurila Oyj, P.O.Box 53, FI-01301 Vantaa, Finland \\ E-mail: kyosti.rajaniemi@oulu.fi, \\ mari.raulio@tikkurila.com \\ sari.tuomikoski@oulu.fi \\ ulla.lassi@oulu.fi
}

\begin{abstract}
Water is crucial to all life forms on earth. Still, millions of people are suffering from a lack of fresh water. The one of the most important reasons is industrial pollution. That is why more effective and economical water treatment systems must be developed and studied worldwide. In this study, a new design of continuous electrocoagulation systems is introduced and compared to widely studied batch process systems. This novel design improves the controllability of water flow and electricity.

In the treatment of paint industry wash water, a batch system and a novel continuous electrocoagulation system with an aluminum (Al) anode and an iron (Fe) cathode were used. Two parallel analyses of both processes were conducted, and the average efficiency of chemical oxygen demand (COD) and Al removal were $68 \%$ and $79.8 \%$ in batch and $69.7 \%$ and $62.1 \%$ in the continuous system, respectively. The number of microbes decreased by $99.6 \%$ in the batch and by $99.8 \%$ in the continuous system. The calculated operational costs in this experiment were $1.63 € / \mathrm{m}^{3}$ for the batch and $1.19 € / \mathrm{m}^{3}$ for the continuous system. The novel continuous electrocoagulation process was as efficient as the batch process in this study.
\end{abstract}

Keywords: electrocoagulation; continuous; wastewater; operational costs; microbial cells, aluminum removal, COD removal.

\section{INTRODUCTION}

Water is the most important and vital matter for all life on earth. Access to fresh water is crucial to human life. About $96.5 \%$ of all water in the earth is in oceans and only a minority is fresh water. About half of this fresh water is in ice caps, glaciers and permanent snow, which are melting rapidly. [1, 2, 3, 4]. In 2010 United Nation (UN) has stated that water and sanitary are universal human rights [5]. Unfortunately these 
rights have not been fulfilled. Dealing with water pollution and scarcity has become one of the biggest challenges in the world due to the significant increase in the human population, urbanization, industrialization, etc. [5].

Electrocoagulation is a water treatment system that has been investigated widely over the past few decades. Electrolysis was invented in late $19^{\text {th }}$ century [6], and Francis Edward Elmore is said to have invented electrocoagulation as a water treatment system [7, 8]. The first such plants, which used Fe electrodes and seawater as a chlorine source, were built in 1889 in London and Salford, England. The first electrolysis plants in the U.S. were built in 1911 in Santa Monica, California and Oklahoma City, Oklahoma [6]. There have been several different electrocoagulation systems invented since early $20^{\text {th }}$ century. $[9,10,11]$.

There are two main types of electrocoagulation treatment: continuous and batch. In the literature many different kinds of systems for both of these processes can be found $[9,10,11,12]$. Some earlier continuous processes are modifications of batch processes like those that Makesh et al $[13,14]$ used. There is a need to improve the controllability of these processes. In this study, a novel continuous electrocoagulation system (NCEC) is introduced with advanced electricity and flow control. This NCEC system is compared to a batch process system that was used in our earlier studies [15, 16]. In addition, operational costs has been calculated for both processes.

\section{ELECTROCOAGULATION METHODS}

Electrocoagulation (EC) has been used since 19th century, and it is known as an environmentally friendly technology. The electrocoagulation process is a combination of coagulation, oxidation and flotation, and gives electricity an important role in water treatment [9]. Electrocoagulation studies have been done in many different fields like the agriculture and food industry [17, 18, 19], nutrient removal [20,21, 22], microbial, bacterial or pharmaceutical removal $[23,24,25]$, metal removal $[26,27,28]$ and other industrial water treatments $[29,30]$.

There are three main types of electrocoagulation system in terms of electrode arrangements, and typically direct current (DC) is used in such systems [31, 32, 33]. These electrode arrangements are parallel monopolar electrodes connections (MP-P), series monopolar electrodes connections (MP-S) and series bipolar electrodes connection (BP-S). [32, 33, 34, 35]. Figure 1 presents the differences between MP-P, MP-S and BP-S connections. 

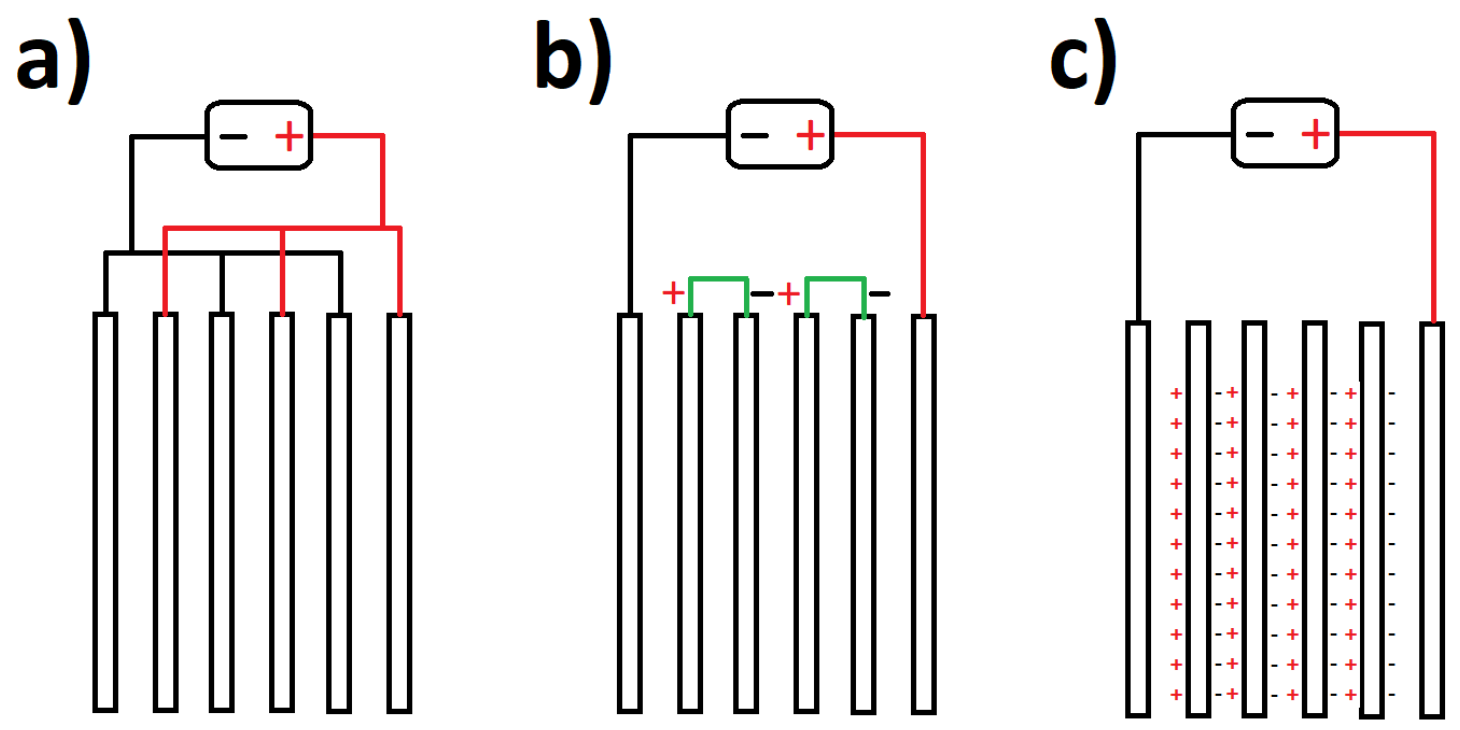

Figure 1. Different electrode connections in electrocoagulation systems. a) MP-P, b) MP-S and c) BP-S connections. [32]

In the MP-P system, the current is divided between electrodes. In the MP-S system, each sacrificial electrode is internally connected to each other. In BP-S, only outer electrodes are connected to the power supply, and only inner electrodes are bipolar, whereas outer electrodes are monopolar. [32, 33, 34].

\subsection{Continuous electrocoagulation}

Typically, continuous electrocoagulation system use one of two possible types of channels: single or multiple channels. In a single channel solution, movement occurs between various numbers of electrode pairs only once. In a multiple channel system, channels work simultaneously, and water flows through one electrode cap [12]. The Figure 2 presents the difference of these two channel flows. On the left side water is going through multiple similar channels and on right side through the single channel.

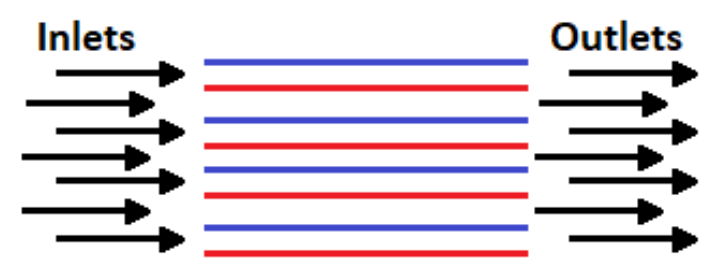

a ) multiple channels

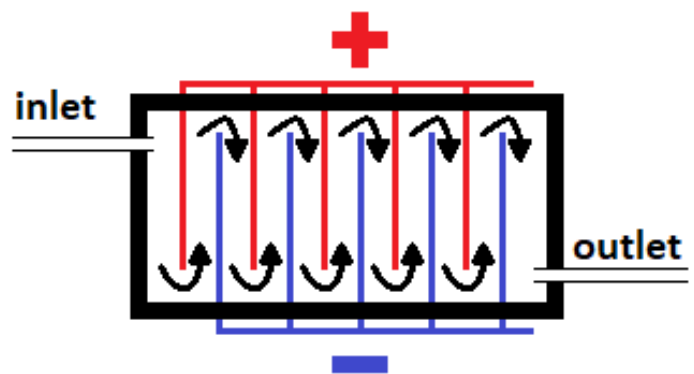

b) single channel

Figure 2. Different flows in continuous electrocoagulation systems, modified from Chen [12]. 


\subsubsection{Novel continuous electrocoagulation system (NCEC)}

The idea of the NCEC system is simple. Water is forced to go between the anode and cathode at a velocity that can be easily adjusted, and there can be numerous pairs of electrodes in a series, but not connected. The gap between electrode pairs is so wide that electricity does not go between two separate electrode pairs. These electrode pairs are perpendicular to the water flow. The first plate is above the water level and blocks the water from spilling over the plate. There is an opening in the bottom of the first plate through which water is forced to go into the active area of the electrodes. The height of the inlet of water can be placed anywhere between the bottom of the housing to the height of the lower electrode. The Figure 3 presents the basic idea of water flow, and the Figure 4 presents top-down view of the system.

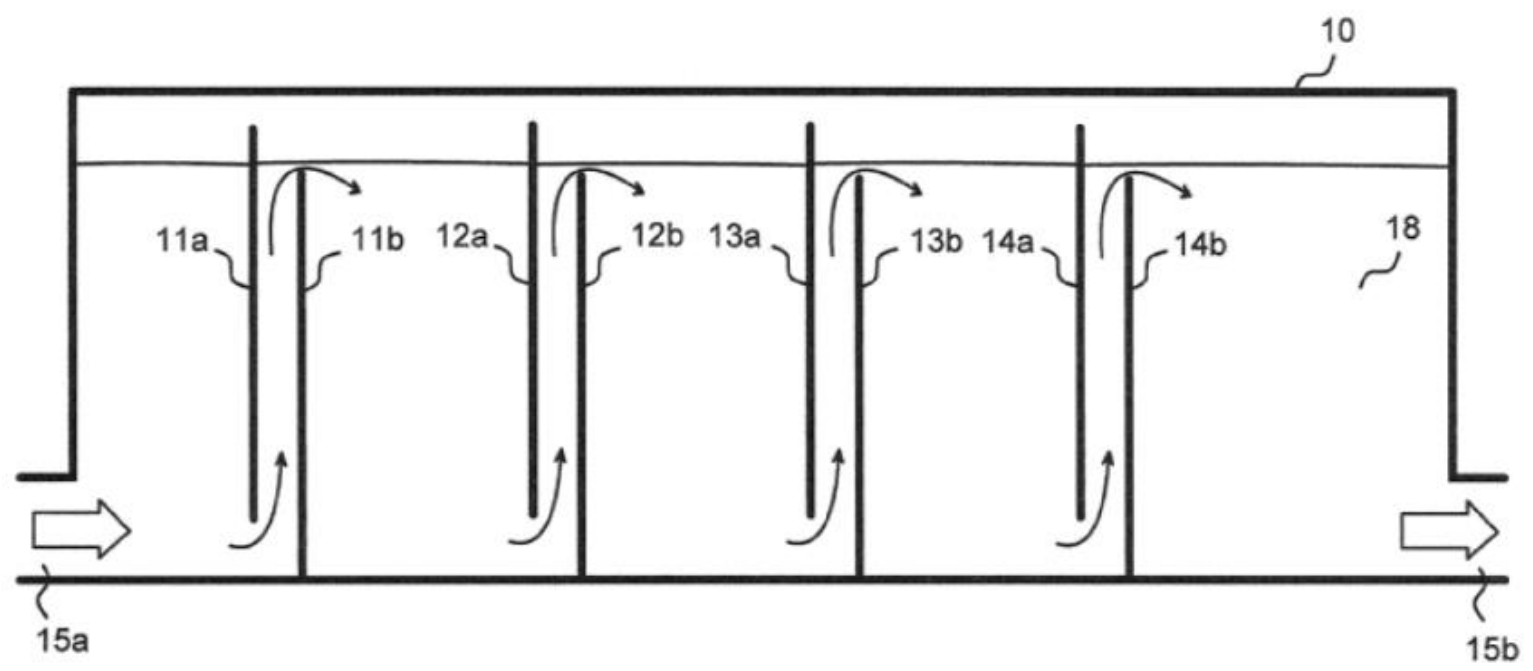

Figure 3. Profile illustration of the NCEC system's water flow from patent FI20165317 [36]. Numbers 11, 12 and 13 presents electrodes where $a$ and $b$ can be either anode or cathode. Numbers $15 \mathrm{a}$ and $15 \mathrm{~b}$ present the inlet and outlet of water flow. Number 10 is the container, and 18 represents treated water.

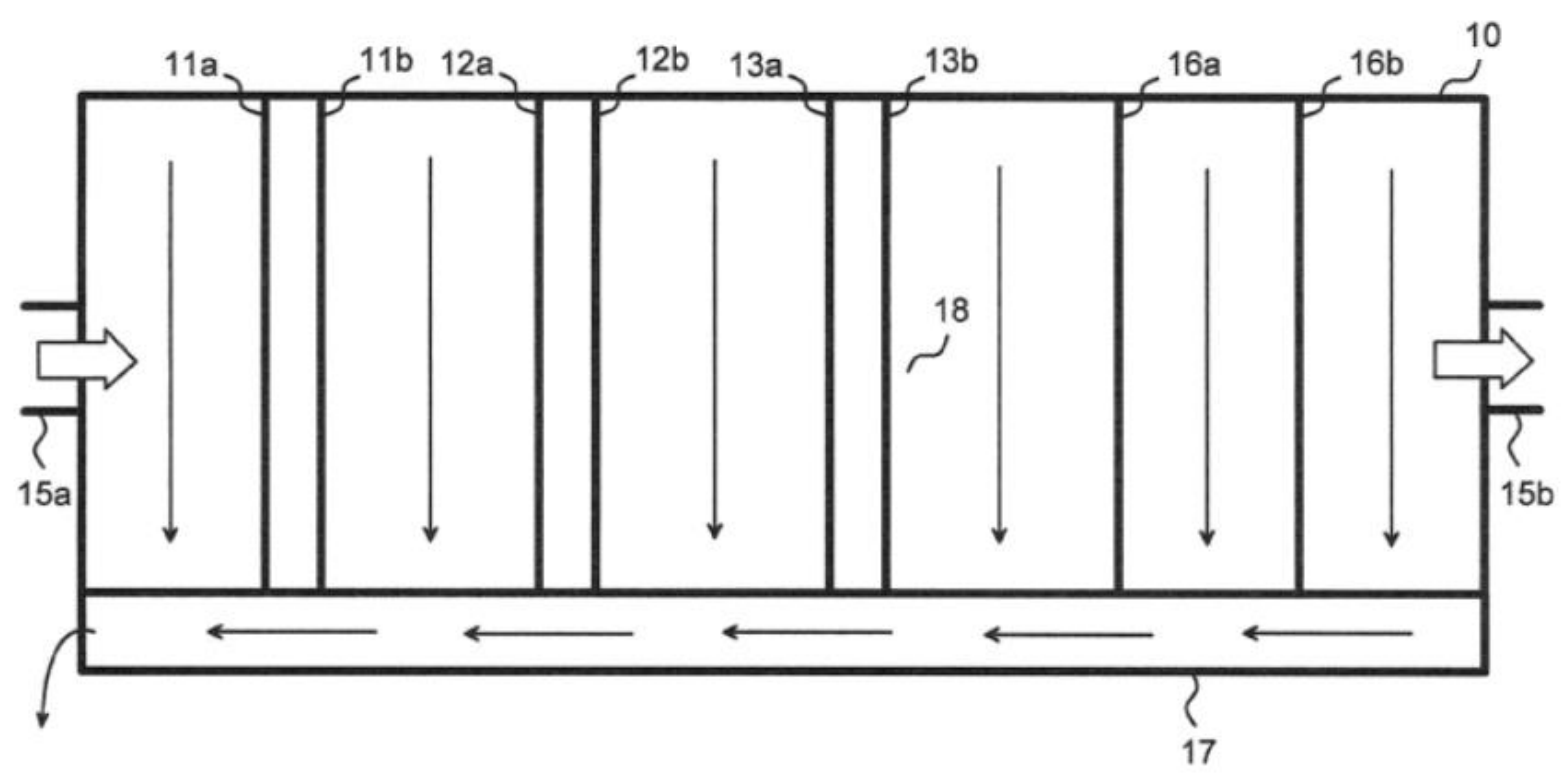


Figure 4. Illustration from the patent FI20165317 [36] from the top of the NCEC system showing sludge flow. Numbers 11,12 and 13 indicate electrodes where $a$ or $b$ can be either anode or cathode. Numbers $15 \mathrm{a}$ and $\mathrm{b}$ present the inlet and outlet of water flow. Number 10 is the container, $16 \mathrm{a}$ and $\mathrm{b}$ indicate non-active plates, and 18 represents treated water. Number 17 indicates a chute that leads sludge out of the system. Thinner arrows denote sludge flow.

The number of electrode pairs is not limited in the NCEC. The power source feeds electricity to electrode pairs. There can be one power source for all electrode pairs or one power source for each electrode pair, which allows a better feed of current to the electrode pairs and to the treated water, or something between these two. The NCEC used in this study had MP-P electrode connections when only one power source was used. Multiple power sources allow for a multiple MP-P system. When the user can adjust the current freely, this enables sending different currents to each electrode pair. Several different electrode materials can be used in this NCEC simultaneously, which is not possible in many other continuous or batch process systems. The flow system in NCEC is a single channel flow with multiple electrode pairs. Between the electrode pairs, sludge forms on the top of the water, or in some cases on the bottom of the container.

\subsubsection{Different continuous EC systems}

Mahesh et al [13] define a continuous electrocoagulation system in their study. This system operates with principles of batch processes, and it uses a MP-P electricity feed. In this system, water is stirred with a magnetic stirrer. This system is presented as a batch system Mahesh et al [14] in their previous studies. The main differences between this continuous system and the introduced NCEC is that this system's water is collected with sludge in a separate tank, while in the NCEC system, treated water and sludge are removed using separate outlets, which lowers the contamination risk of treated water. Kobajah et al [37] introduces continuous system similar to Mahesh et al's [14] batch design. The inlet is on the bottom of the system, and the sludge in this system is separated from treated water (Figure 5). The main difference between this and the NCEC is that water can flow freely into a reactor in this system, while in the NCEC, the treated solution is forced to pass electrodes at a desired velocity. 


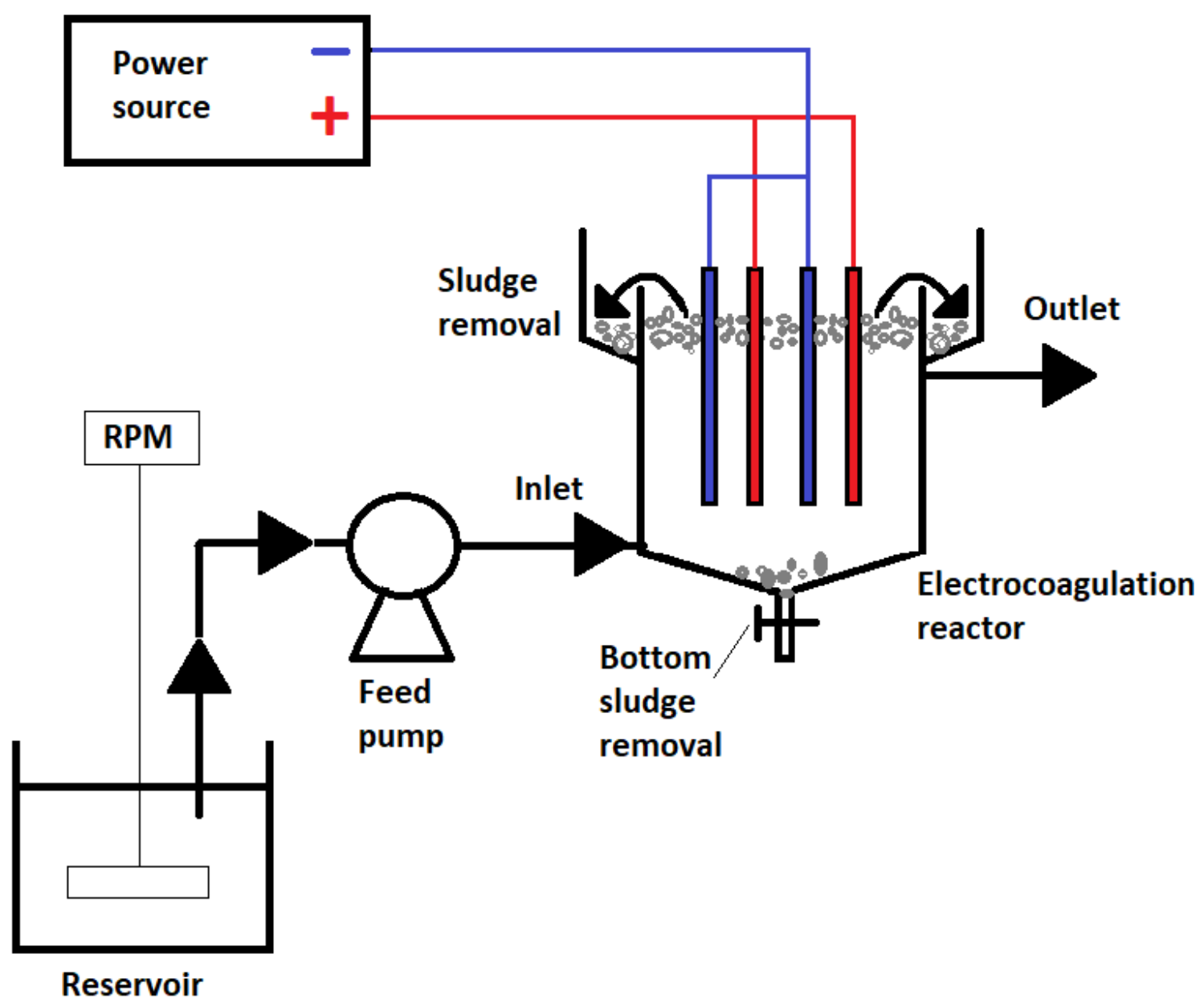

Figure 5. Continuous process improved from batch process. Figure is modified from Mahesh et al [13].

Kim et al [38] presented their system of continuous electrocoagulation in Figure 6. In this system the gaps between electrode pairs are the same as those between anode and cathode. This is different from the NCEC, which leaves space between each electrode pair so water can settle and formed sludge can be collected before the next electrode pair. The treated solution is always cleaner than it was in the previous electrode pair, and the treatment process can be more efficient. 


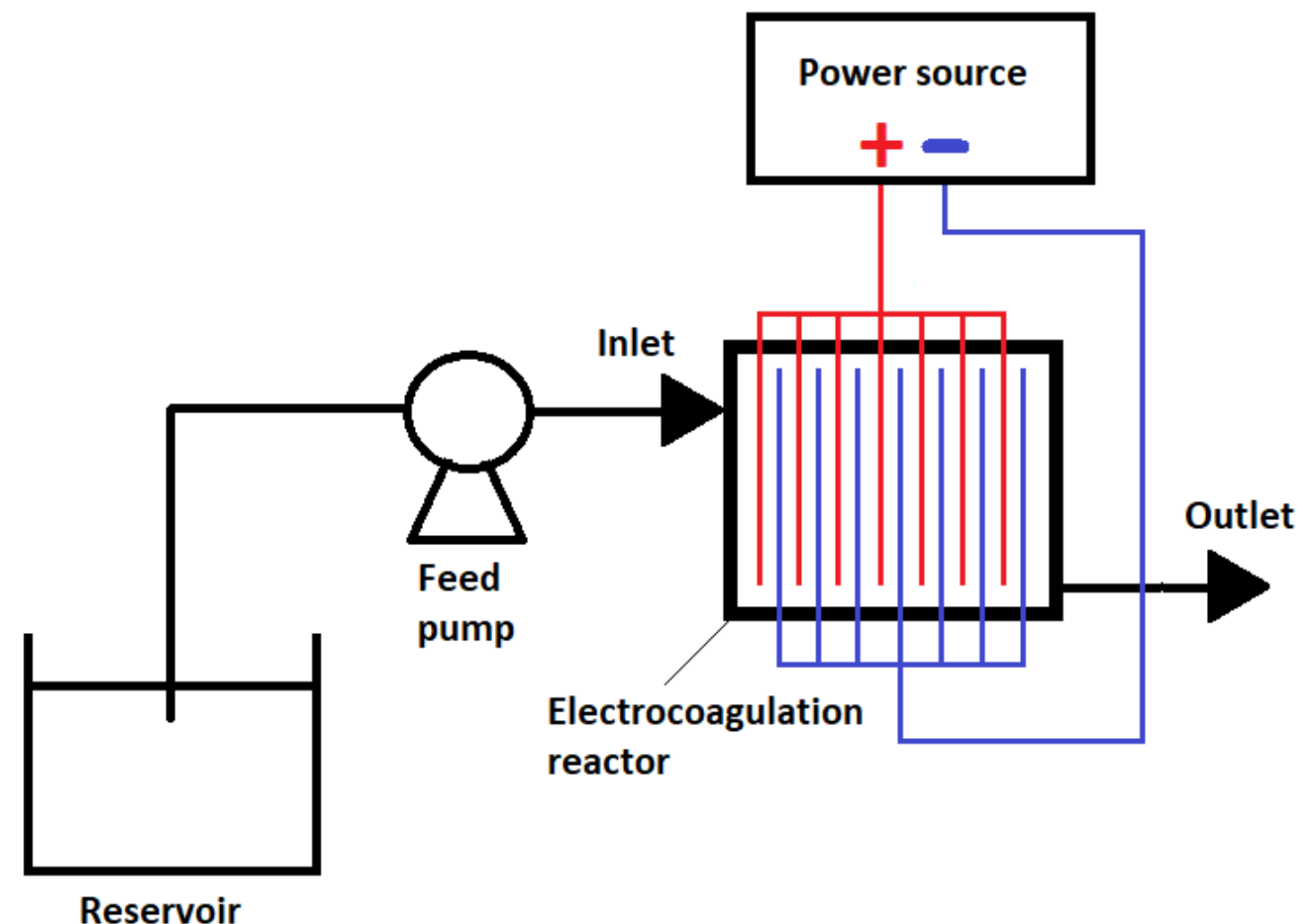

Figure 6. One continuous electrocoagulation system. Figure is modified from Kim et al [38].

Patent WO2007050041 [39] describes an invention in which water is treated by electrocoagulation and electro-catalytic principles. The purpose of the two different cells is to treat different substances. This system has round electrode plates and it has holes near its peripheral edge through which water can flow. This system has two to four "wings" that move water towards the edges. The main difference to the NCEC is that electrocoagulation in the NCEC is active only in the gap between anode and cathode electrodes.

Patent WO2015187511 [40] discloses an electrocoagulation chamber that has vertical electrode plates and is partly pressurized. The water is fed into the chamber from inlet "30" below. The water is then directed up between the electrode plates in a normal atmosphere. After the electrocoagulation, the water flows upwards and falls over the edge into an inter-wall volume. Typically, the electrocoagulation sludge/foam rises to the surface of the water, and in this patent, this foam contains extra liquid that flows over the edge to the cylindrical inter-wall volume and exits the housing through a chute. The main difference to the NCEC is that this system has a pressurized part, which increases the energy consumption. The NCEC system has not any pressurized part.

Patent 4217/89 (HUT63119) [41] discloses an electroflotation cell for treating wastewater. The reaction space comprises vertical plate-type anodes and cathodes arranged in parallel and connected to a direct current source. The negative and positive plates are placed alternately. The lower ends of the electrode plates are provided with a plurality of holes. The wastewater swirls down and up within each of the intermediate gaps between the plates. The excess foam flows up onto the top of the liquid surface 
and goes out of the electroflotation chamber along a tilted route into a foam container. The foam and the liquid seem to exit the device from the same outlet. The main difference to the NCEC is that this system has angled electrodes and parallel anodes.

Several other kinds of continuous electrocoagulation systems are commonly used to treat or disinfect water. The main problem of many of continuous electrocoagulation systems is that many of those are modifications from batch-system principles and are not directly designed to continuous treatment.

\subsection{Batch electrocoagulation}

Batch electrocoagulation processes, which are used at the laboratory scale and in scientific research, involve a container or reactor, a power source, electrodes and a stirrer. In most cases, water is stirred with a magnetic stirrer or overhead stirrer. The main idea of almost every batch system is to treat water with hanging electrodes. The number of electrode pairs differs between processes. [12, 17, 18]. The main differences in batch processes are in the size, the cap between electrodes as well as materials of the electrode pairs.

There are two basic systems of batch processes: multiple-electrode and singleelectrode pair systems (Figure 7). With multiple electrode pairs, the electricity feed system can be MP-P, MP-S or BP-S [32, 33, 34, 35]. Single pair always uses an MP$P$ electricity feed system.

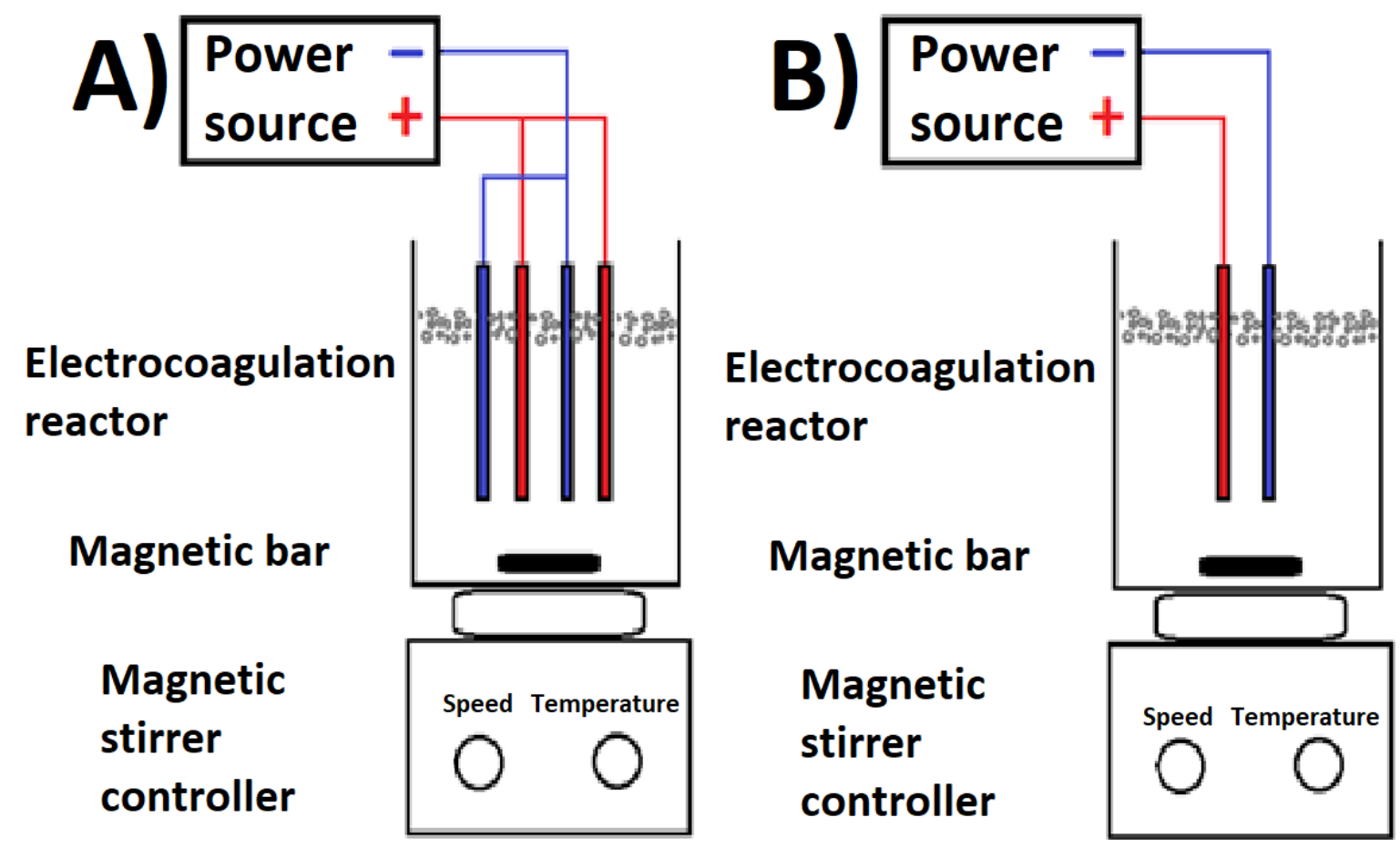

Figure 7. Basic setup of batch electrocoagulation systems. A) presents multiple electrode pairs and B) presents a single electrode pair. [38, 15]. Multiple electrode pairs can use MP-P, MP-S or BP-S electricity feed systems. Single-pair always uses an MP-P electricity feed system. 


\section{METHODS AND MATERIALS}

\subsection{Laboratory scale novel continuous process electrocoagulation equipment}

The main idea of continuous electrocoagulation systems is similar to that of the system described in the bending patent, Fl20165317 [36], in which the first author is the main inventor. Figures 3 and 4 present schematic pictures of the system. All the equipment needed for continuous electrocoagulation was planned and built for this study. This continuous electrocoagulation included the following parts: 10-liter glass tank as a reservoir for paint industry wastewater, 3D-printed container (length $500 \mathrm{~mm} \times$ wide $110 \mathrm{~mm} \times$ height $120 \mathrm{~mm}$ and total volume of $4075 \mathrm{~cm}^{3}$ ) using black acrylonitrile butadiene styrene (ABS) 3D filament and container was painted outside and inside with black paint (Biltema, art. 36-7408) to cover possible holes from 3D printing process. The container was used several times before these tests, and no paint residue was found.

Electricity was applied with one power supply EA-PS 3016-40 B (16 V/40 A) and power was applied to all four electrode pairs in paint industry wash water treatment. In the NCEC system, the electrode pairs were Al - Fe electrodes in which Al was the anode and $\mathrm{Fe}$ was the cathode. The fifth pair was not connected to power source and it acted as spacer. The electrode cap was $5 \mathrm{~mm}$ in all electrode pairs. The synthetic wastewater was pumped into the electrocoagulation container using a Watson Marlow's 120 S/DV Pump with the flow of $8 \mathrm{~L} / \mathrm{h}$. The diameter of the rubber feedline was $8 \mathrm{~mm}$, with a wall thickness of $1.5 \mathrm{~mm}$. Two types of electrodes were used in the continuous process (see Figure 8). Unless otherwise stated, all measures are in millimeters. Only one side of a continuous process electrode was calculated as the effective area of the electrode because there was no evidence of any sacrifice in the outside of an anode electrode. The total area of effect was $307.2 \mathrm{~cm}^{3}$. The total current was set to $10 \mathrm{~A}$. The first and second electrode pairs had currents of $3 \mathrm{~A}$, while the third and fourth electrode pairs had currents of 2.5 A. All the cleaning procedures are described in Kuokkanen et al [15].
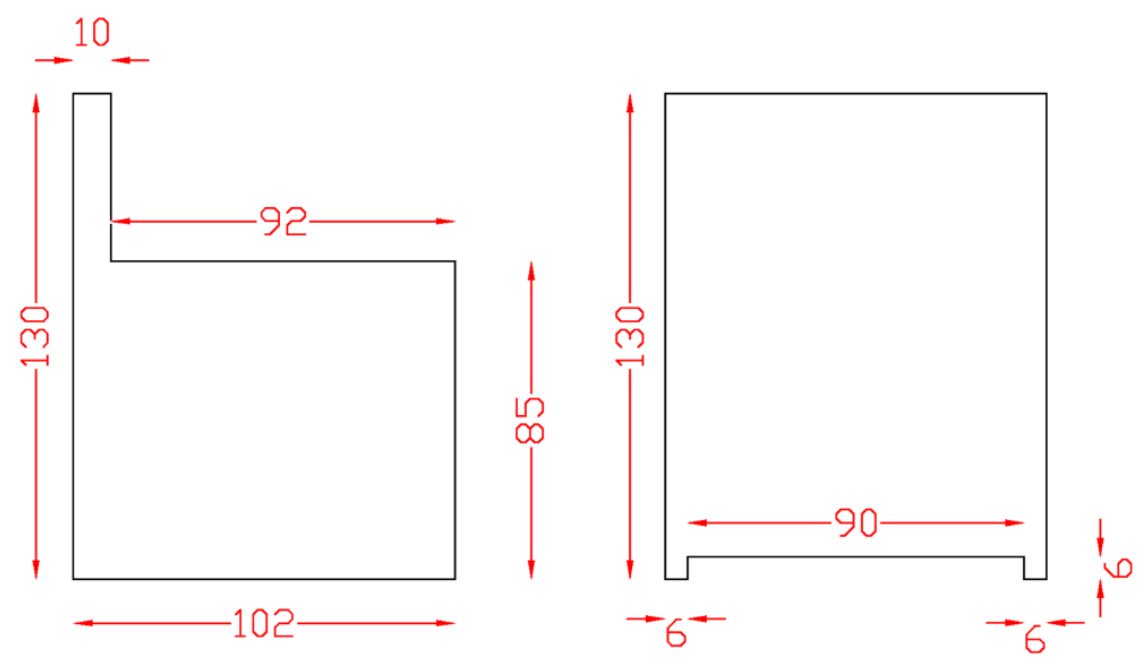

Figure 8. Two types of electrodes in the continuous electrocoagulation system used. The thickness of the each electrode was $3 \mathrm{~mm}$. 


\subsection{Laboratory scale batch process electrocoagulation equipment}

A single-pair electrocoagulation system was used in this study. The system is described in more detail in earlier studies $[15,16]$. The laboratory-scale batch process electrocoagulation equipment is similar to the system described in Kuokkanen et al. [15], and the total volume of the wastewater was 1.8 liters. This system includes all the same components except the power supply, which was EA-PS 3065-05 B. This power source could be adjusted; current from 0 to $5 \mathrm{~A}$ and voltage from 0 to $65 \mathrm{~V}$. The size of the electrodes was $50 \mathrm{~mm} \times 50 \mathrm{~mm} \times 10 \mathrm{~mm}$, with a total area of effect of $70 \mathrm{~cm}^{2}$ and the current set to $1 \mathrm{~A}$. The electrode cap between electrodes was set to $5 \mathrm{~mm}$. All the cleaning procedures were the same as these described in Kuokkanen et a [15].

\subsection{Authentic paint industry wash water}

In this study, the paint industry wash water was treated with the NCEC and the batch systems. The efficiency of the purification process was studied using three parameters: chemical oxygen demand, Al content of wash-water and the number of viable microbial cells. These parameters are crucial when evaluating the potential to re-use of wash water in paint industry processes. In non-treated wash water, these values were 8750 $\mathrm{mg} / \mathrm{L}, 94 \mathrm{mg} / \mathrm{L}$ and 3.977 million CFU / $\mathrm{ml}$, respectively. The $\mathrm{pH}$ of the wash water was 6.6; conductivity was $445 \mu \mathrm{S} / \mathrm{cm}$; and the color was white.

The paint industry wash water sample used in this study was collected from a storage tank into clean plastic canister. The wash water from cleaning the paint manufacturing vessels and other equipment is collected into this tank. Altogether approximately 40 $50 \mathrm{~m}^{3}$ of water is running through this storage tank in a week. The tank is equipped with a stirrer and BTEX sniffer. If any BTEX is detected, the water is aerated. From this tank, the wash water is directed to the treatment and after to municipal wastewater treatment.

\subsection{Analytical methods}

Water samples for analysis were collected during the batch process every five minutes and at the end of process after two minutes of resting time. During the continuous process, samples were collected in every different area that the equipment possesses, for a total of five samples/test. The chemical oxygen demand and Al were measured according to the ISO 15705:2002 and ISO 15587-2:2002 standards, respectively. Because the COD values were higher than $1000 \mathrm{mg} /$ liter, predilution was used. Removal efficiency percent (RE) of COD and Al from those samples were determined using the equation 1 :

$$
R E=\frac{c \times c_{0}}{c_{0}}
$$

Where $\mathrm{C}_{0}$ and $\mathrm{C}$ are initial and final absorbance of COD or $\mathrm{Al}$ before and after electrocoagulation [10]. The current density (i) is calculated using equation 2 [10]: 
$i=\frac{I}{A_{\text {eff }}}$

Equation 2

where

I = current $[\mathrm{A}]$

Aeff $=$ effective area of electrodes $\left[\mathrm{m}^{2}\right]$.

The number of viable microbial cells was determined by culturing ten-fold dilutions (ster $0.9 \% \mathrm{NaCl}$ solution) of water samples on Tryptic Soy Agar (TSA, Merck 105458, Darmstadt, Germany) plates in duplicates. The plates were incubated in $28^{\circ} \mathrm{C}$ for 4 days, and the number of colony-forming units per $\mathrm{mL}$ of water (CFU / $\mathrm{mL}$ ) was calculated from the weighted average of parallel plates, taking the dilution factor into account.

\subsection{Operational costs of EC}

The operational costs $(\mathrm{OC})\left[\mathrm{kWh} / \mathrm{m}^{3}\right]$ of processes were calculated after the tests [11, 34]. Total operational costs in this experiment included the following variables: electrical energy consumption (EEC) $\left[\mathrm{kWh} / \mathrm{m}^{3}\right]$, mass of anodic material dissolved $(E M C)\left[\mathrm{kg} / \mathrm{m}^{3}\right]$, industrial energy price $(a)[€ / \mathrm{kWh}$ ], price of electrode material $(b)[€ / \mathrm{kg}]$, current in process $(\mathrm{I})[\mathrm{A}]$, voltage of process $(\mathrm{U})[\mathrm{V}]$, time used (t) [min] and volume of treated water $(\mathrm{V})\left[\mathrm{m}^{3}\right]$. In this paper, the following equations were used:

$O C=a \times E E C+b \times E M C$

Equation 3

$E E C=\frac{U \times I \times t}{60 \times V}$

Equation 4

The following parameters were used in this study: an industrial energy price of 0.09 $€ / \mathrm{kWh}$ (average in November 2018 in Finland, including energy price, distribution price and taxes) and an estimated price of aluminum of $1.755 € / \mathrm{kg}$. The time, volume, current and voltage were 30 minutes, 1.8 liters, $59.5 \mathrm{~V}$ and $1 \mathrm{~A}$, respectively in the batch process and 60 minutes, 8 liters, $20.2 \mathrm{~V}$ and $5 \mathrm{~A}$, respectively in the continuous process.

Equations 3 and 4 are suitable for the NCEC process because all variables in these equations are available in that case. In the continuous process, total electrical energy consumption is calculated from all electrode pairs, dissolved anode mass is measured from all four anodes and volume and time are determined from the water flow used during the experiment.

\section{RESULTS AND DISCUSSION}

The calculated current density was $142 \mathrm{~A} / \mathrm{m}^{2}$ for the batch process and $144 \mathrm{~A} / \mathrm{m}^{2}$ for the continuous process. The $\mathrm{pH}$ value did not significantly change during the electrocoagulation process (from 6.6 to 7.15 in the batch process and from 6.6 to 7.0 in the continuous process). It is notable that the systems were not optimized in any way. Authentic paint industry wash water was not pretreated before the continuous and 
batch electrocoagulation processes to find out how these processes are suitable to be the only water treatment method to this water.

\subsection{Removal of COD}

The COD removal percent was one of the main characteristics in this study evaluating the suitability of the electrocoagulation process for treating authentic paint industry wash water. Figure 9 presents the COD removal as a function of time (in the batch process) and as a function of chambers (in the continuous process). Total COD removal was $69.7 \%$ in the continuous process and $68.0 \%$ in the batch process. These results indicate that both processes were efficient enough at reducing COD for wash water re-use in manufacturing process. Figure 9 shows that the reduction in the COD value of the wash water after first electrode pair in the continuous process was greater than that of the batch process after 15 minutes. In the batch process, only a small increase in the removal efficiency was measured after 25 minutes. In the continuous process, removal effect increased until the final step.

Continuous process

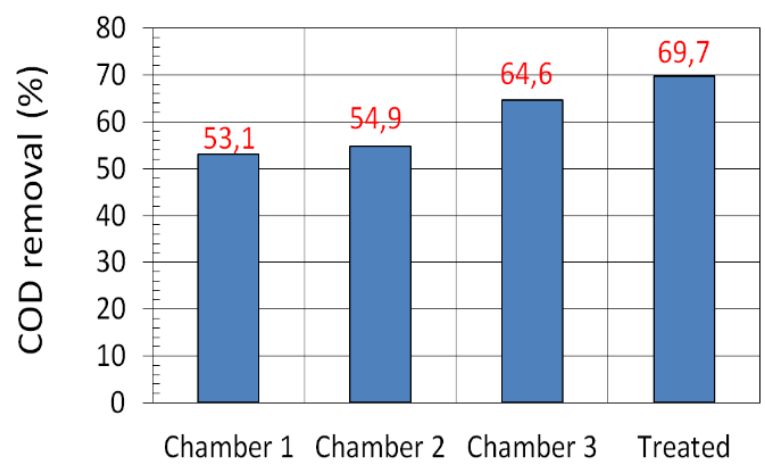

Batch process

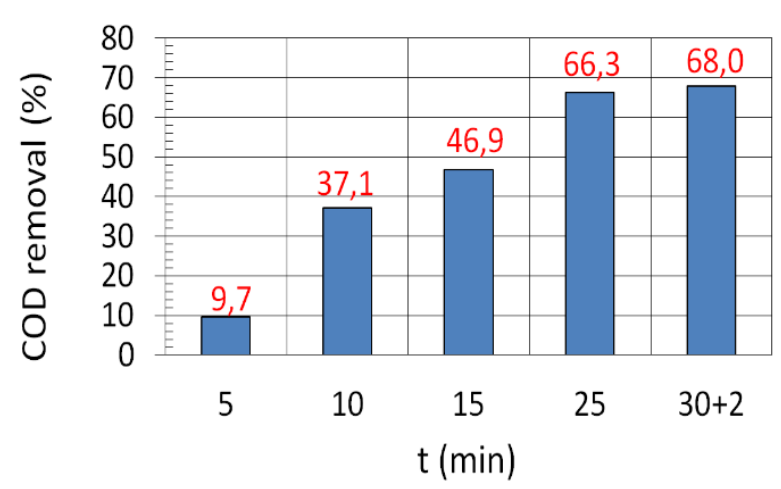

Figure 9. Removal of COD in continuous and batch process.

Zodi et al [29] studied COD removal in a continuous reactor. They reached $48-52 \%$ COD removal with current density of $100 \mathrm{~A} / \mathrm{m}^{2}$ and $69-76 \%$ with current density of $200 \mathrm{~A} / \mathrm{m}^{2}$. In this study, the current density was $144 \mathrm{~A} / \mathrm{m}^{2}$ for the continuous process and the COD removal $70 \%$ was reached. The lower current density is comparative to lower energy consumption. Better COD removal obtained in our study indicates that the current feed to the system is more efficient than in the experiments Zodi et al presented.

\subsection{Removal of Al from wash water}

The efficiency of Al removal from wash water was studied to compare the batch and continuous electrocoagulation processes. Figure 10 presents the Al removal as a function of time (in the batch process) and as a function of chambers (in the continuous process). The removal of aluminum was $62.1 \%$ in the continuous process and $79.8 \%$ in the batch process. These results indicate that both processes are suitable for aluminum removal. The removal percentage did not increase significantly after 25 minutes in the batch process. However, during the continuous process, the removal 
percentage increased until the final step. The aluminum removal in batch process was higher comparing to the continuous process because of differences in equipment geometry and lower mass transfer.
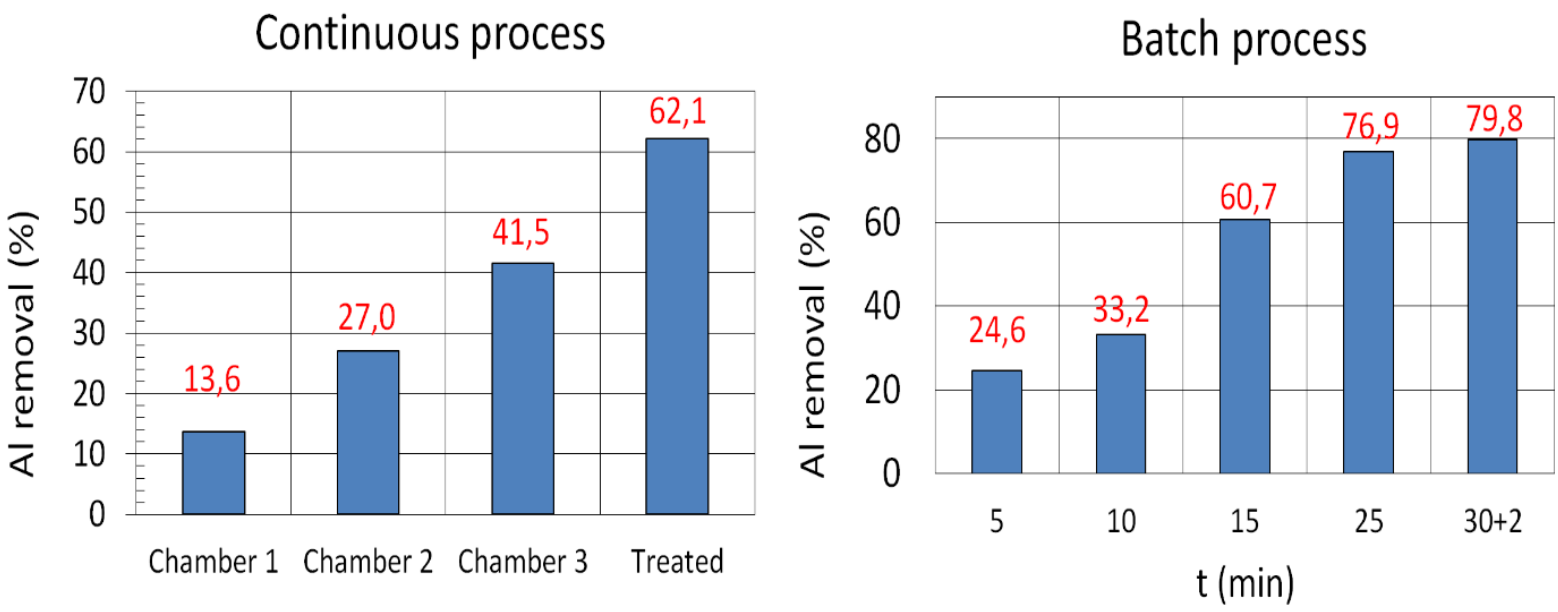

Figure 10. Removal of Al in continuous and batch process.4.3 Disinfection effect of EC treatment

The wash water samples were cultivated to determine the number of viable microbial cells before, during and after the electrocoagulation processes. The results (Figure 10) show that electrocoagulation decreased the number of viable microbial cells in the continuous process by $99.8 \%$ and in the batch process by $99.6 \%$. In both processes, the number of microbial cells decreased. Figure 11 presents the number of viable microbial cells as a function of time (in the batch process) and as a function of chambers (in the continuous process). No significant additional reduction of viable microbes was seen after 25 minutes of treatment in batch process. (from $3.1 \times 10^{4}$ to $3 \times 10^{4} \mathrm{CFU} / \mathrm{mL}$ ). In the continuous process, the reduction rate stayed stable until the final step.

Continuous process

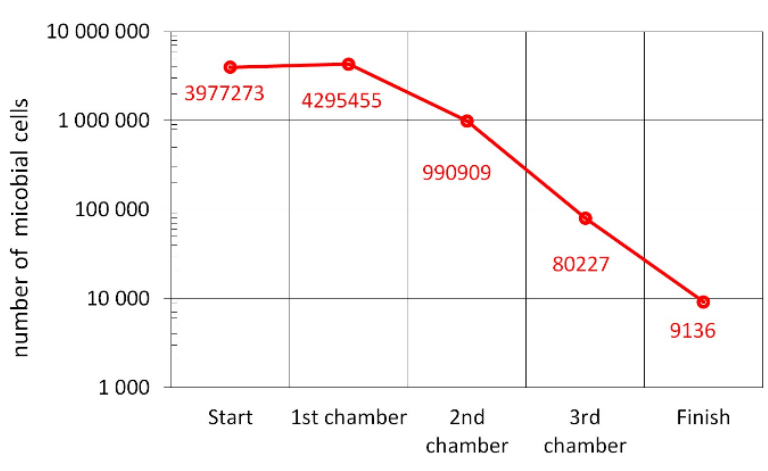

Batch process

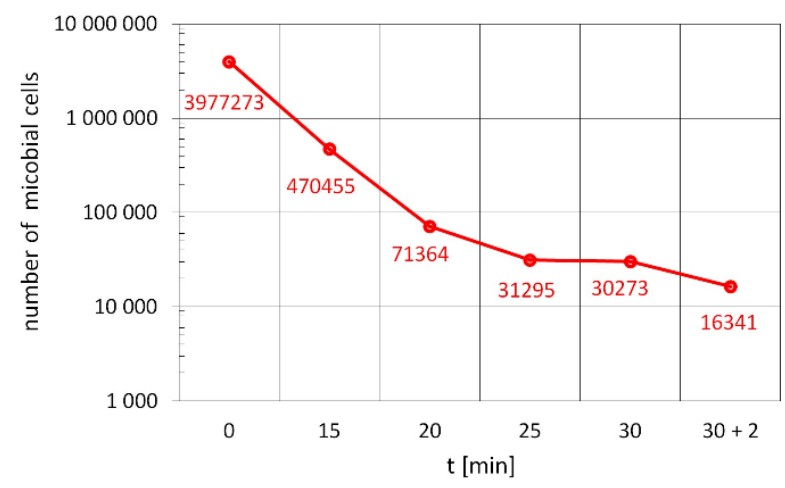

Figure 11. The number of viable microbial cells at different stages of the continuous and batch process

The reduction efficiency of viable microbial cells reached in previous studies [42, 43, 44] are in line with the results obtained in this study. The reduction of viable microbial 
cells in Ghernout at al [42] and Hakizimana et al [43] were almost $100 \%$ as in this study (99,6 \% in batch and 99,8 \% in continuous process). In El-Masry et al had reduction of microbial cells $10^{4}$ which is in line with this study. The comparison of studiespresented in literature is challenging because of the initial difference of microbial cells in different studies.

\subsection{Process economy}

The operational costs of the electrocoagulation system mainly consist of the cost of electricity used. The cost of dissolved metal depends on the material used, but its value is not significant in electrocoagulation. Reported cost estimations from the operation of electrocoagulation systems are compiled in Table 1. However, the costs of different systems are not directly proportional with each other since electrode materials, effluents and other chemicals and the system vary. There are far fewer studies about the operational costs of continuous electrocoagulation systems than about those of batch systems.

Table 1. Operational costs of electrocoagulation systems

\begin{tabular}{|c|c|c|c|c|c|}
\hline Water treated & $\begin{array}{c}\text { Process } \\
\text { type }\end{array}$ & $\begin{array}{c}\text { Anode } \\
\text { material }\end{array}$ & $\begin{array}{c}\text { Total cost } \\
\left(\mathbf{U S D} / \mathbf{m}^{3}\right)\end{array}$ & $\begin{array}{c}\text { Total cost } \\
\left(\mathrm{EUR} / \mathbf{m}^{3}\right)\end{array}$ & Reference \\
\hline $\begin{array}{c}\text { Mining and dairy } \\
\text { wastewater }\end{array}$ & batch & $\mathrm{Al}, \mathrm{Fe}$ & & $0.17-0.31$ & Kuokkanen et al [15] \\
\hline $\begin{array}{c}\text { Synthetic humic acid and } \\
\text { peat dog drainage waters }\end{array}$ & batch & $\mathrm{Al}, \mathrm{Fe}$ & & $0.06-0.15$ & Kuokkanen et al [16] \\
\hline $\begin{array}{c}\text { Petroleum contaminated } \\
\text { groundwater }\end{array}$ & batch & $\mathrm{Al}, \mathrm{Fe}, \mathrm{steel}$ & $0.18-0.73$ & & Kobya et al [33] \\
\hline $\begin{array}{c}\text { Rinse water of zinc } \\
\text { phosphating }\end{array}$ & batch & $\mathrm{Al}, \mathrm{Fe}$ & $4.2-14.5$ & & Kobya et al [37] \\
\hline Waste metal cutting fluids & batch & $\mathrm{Al}, \mathrm{Fe}$ & $0.48-0.79$ & & Kobya et al [45] \\
\hline Oily bilge water & batch & $\mathrm{Al}, \mathrm{Fe}$ & 0.46 & & Asselin et al [46] \\
\hline Dairy wastewater & batch & $\mathrm{Fe}$ & $0.07-2.55$ & & Kushawaha et al [47] \\
\hline $\begin{array}{c}\text { Potato chip } \\
\text { manufacturing }\end{array}$ & batch & $\mathrm{Al}, \mathrm{Fe}$ & $0.48-6.32$ & & Kobya et al [48] \\
\hline $\begin{array}{c}\text { Slaughterhouse } \\
\text { wastewaters }\end{array}$ & batch & steel, Al & 0.71 & & Asselin et al [49] \\
\hline Baker's yeast wastewater & batch & $\mathrm{Al}, \mathrm{Fe}$ & $0.82-1.54$ & & Kobya et al [50] \\
\hline $\begin{array}{c}\text { Rinse water of cadmium } \\
\text { and nickel electroplating }\end{array}$ & batch & $\mathrm{Fe}$ & & $0.17-2.45$ & Kobya et al [51] \\
\hline $\begin{array}{c}\text { Marble processing } \\
\text { wastewater }\end{array}$ & batch & $\mathrm{Al}, \mathrm{Fe}$ & $0.09-2.74$ & & Solak et al [52] \\
\hline Different synthetic waters & batch & $\mathrm{Fe}$ & 0.11 & & Wan et al [53] \\
\hline $\begin{array}{c}\text { Synthetic fluoride solution } \\
\text { Bio-oil and synthetic oil }\end{array}$ & $\begin{array}{c}\text { batch } \\
\text { wirculation }\end{array}$ & $\begin{array}{c}\mathrm{Al} \\
\text { stainless }, \mathrm{Al}\end{array}$ & $0.07-1.61$ & & Behbahani et al [54] \\
\hline
\end{tabular}




\begin{tabular}{|c|c|c|c|c|c|}
$\begin{array}{c}\text { Pulp and paper mill } \\
\text { wastewater }\end{array}$ & continuous & Fe & 0.9 & Mahesh et al [Error! \\
\hline $\begin{array}{c}\text { Synthetic wastewater } \\
\text { (red dye) }\end{array}$ & continuous & $\mathrm{Al}$ & $\begin{array}{c}0.34-0.53 \\
\$ / \mathrm{kg} \text { dye }\end{array}$ & & Merzouk et al [56] \\
\hline Dyehouse wastewater found.]
\end{tabular}

Based on the average current and voltage, the usage of electricity per cubic meter of treated water was $16.53 \mathrm{kWh} / \mathrm{m}^{3}$ in the batch process and $12.53 \mathrm{kWh} / \mathrm{m}^{3}$ in the continuous process. The electrode material consumption in the batch and continuous processes were $0.083 \mathrm{~kg} / \mathrm{m}^{3}$ and $0.033 \mathrm{~kg} / \mathrm{m}^{3}$, respectively.

Based on the calculations, the operational costs were $1.63 € / \mathrm{m}^{3}$ for the batch process and $1.19 € / \mathrm{m}^{3}$ for the continuous process. As shown in Table 1, the total operational costs of continuous electrocoagulation systems are reported to vary between 0.26 to $20 € / \mathrm{m}^{3}$. The operational costs of the system used in this study are in the lower part of the variation, but these costs depend on many different factors, as stated in Equation 3 , and cannot be compared directly with those of other systems introduced in table 1 .

\section{CONCLUSIONS}

Lot of studies have been reported on both continuous and batch electrocoagulation systems. In this paper, we introduced a NCEC system, which is compared to a batch system. The aim of this study was to compare the efficiency of NCEC and batch process electrocoagulation equipment in the treatment of paint industry wash water. Comparisons of these two systems were made based on four parameters: COD content, aluminum content, the number of viable microbial cells and operating costs. Both systems efficiently decreased COD and aluminum content, as well as the number of viable microbial cells.

The COD removal was slightly higher in the continuous process compared to the batch process and the results were in-line with previously reported studies reduces with a lower current density which makes NCEC system more efficient than system used in the study of Zodi et al. Aluminum removal in the batch process was much higher than in the continuous process due to differences in equipment geometry and lower mass transfer. Although a significant reduction of viable microbial cells was detected in the 
wash water after the electrocoagulation process $(99.6 \%$ in the batch process and $99.8 \%$ in the continuous process), the reason for the reduction remains unclear. The microbes attached to solid particles most probably outnumber the planktonic microbes present in the water, and thus the coagulation of solid materials reduces the number of microbes naturally which has been shown in earlier studies. The calculated operational costs were about $37 \%$ higher in the batch process than in the continuous process. Overall, the NCEC process was efficient in reducing COD, aluminum and number of viable microbial cells, and its economic efficiency was much higher than that of the conventional batch process.

\section{ACKNOWLEDGEMENTS}

Kyösti Rajaniemi would like to thank Erkki Paasikiven säätiö for funding his study. Authors would like to thank Tikkurila Oyj Maintenance and Microbiological laboratory for skillful assistance and Ahma Ympäristö Oy for the chemical compounds analytics.

\section{References}

1. I. A. Shiklomanov. World fresh water resources in Water in Crisis: A guide to the World's Fresh Water Resources. Edited by P.H. Gleick, pp 13-24, Oxford Univ. Press, New York, 1993.

2. A. Jiménez, M. Cortobius and M. Kjellén, Water, sanitation and hygiene and indigenous peoples: a review of the literature. Water Int, 39 (2014) 277-293.

3. K. Watkins. Human Development Report 2006 - Beyond Scarcity: Power, Poverty and the Global Water Crisis. UNDP Human Development Reports (2006). Electrically available at SSRN: https://ssrn.com/abstract=2294691 (Accessed March 8, 2019).

4. NOAA National Centers for Environmental Information, State of the Climate: Global Climate Report for Annual 2017. Electrically available from:

https://www.ncdc.noaa.gov/sotc/global/201713 (accessed March 8, 2019).

5. UN General Assembly 2010. Resolution 64/292. The human right to water and sanitation. A/Res/64/292 given July 28, 2010.

6. J.N. Hakizimana, B. Gourich, M. Chafi, Y. Stiriba, C. Vial, P. Drogui and J. Naja. Electrocoagulation process in water treatment: a review of electrocoagulation modeling approaches. Desalin., 404 (2017) 1-21.

7. F. E. Elmore, 1905. Improvements in processes and apparatus for separating certain constituents of finely dividen material by causing them to rise or float in a liquid, GB190417816 https://fi.espacenet.com/publicationDetails/biblio?DB=EPODOC\&II=28\&ND=3\&adjace

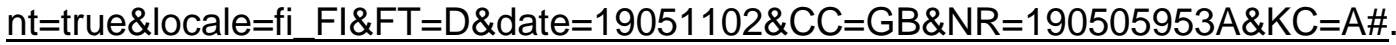
(Accessed March 1, 2019).

8. F. E. Elmore, 1904. A process for separating certain constituents of subdivided ores and like substances, and apparatus therefore, GB190413578

https://fi.espacenet.com/publicationDetails/biblio?DB=EPODOC\&ll=31\&ND=3\&adjace

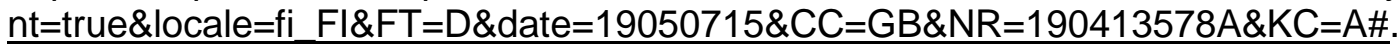
(Accessed March 1, 2019).

9. J. Liu, G. Zhu, P. Wan, Z. Ying, B. Ren, P. Zhang and Z. Wang, Current applications of electrocoagulation in water treatment: a review, Desalin. Wat. Treat., 74 (2017) 5370. 
10. D.T. Moussa, M.H. El-Naas, M. Nasser and M.J. Al-Marri. A comprehensive review of electrocoagulation for water treatment: potentials and challenges. J. Environ. Manag., 186 (2017) 24-41.

11. V. Kuokkanen, T. Kuokkanen, J. Rämö and U. Lassi. Recent Applications of Electrocoagulation in Treatment of Water and Wastewater-A Review. Green and Sustainable Chemistry, 3 No. 2, (2013) 89-121.

12. G. Chen. Electrochemical technologies in wastewater treatment, Sep. Pur. Tech., 38 (2004) 11-41.

13. S. Mahesh, K. K. Garg, V.C. Srivastava, I. M. Mishra, B. Prasad and I. D. Mall. Continuous electrocoagulation treatment of pulp and paper mill wastewater: operating cost and sludge study, RSC Adv., 06 (2016) 16223-16233.

14. S. Mahesh, B. Prasad, I.D. Mall and I.M. Mishra. Electrochemical degradation of pulp and paper mill wastewater. Part I. COD and color removal. Ind. Eng. Chem. Res., 45 (2006) 2830-2839.

15. V. Kuokkanen, T. Kuokkanen, J. Rämö, U. Lassi and J. Roininen. Removal of phosphate from wastewaters for further utilization using electrocoagulation with hybrid electrodes - Techno - economic studies. J. Wat. Proc. Eng., 8 (2015) e50 e57.

16. V. Kuokkanen, T. Kuokkanen, J. Rämö and U. Lassi. Electrocoagulation treatment of peat bog drainage water containing humic substances. Wat. Res., 79 (2015) 79-87.

17. U Tezcan and E. Ozel. Electrocoagulation of yogurt industry wastewater and the production of ceramic pigments from the sludge. Sep. Pur. Tech., 120 (2013) 386391.

18. K. Bensadok, N. El Hanafi and F. Lapicque. Electrochemical Treatment of Dairy Effluent Using Combined Al and Ti/Pt Electrodes System, Desalin., 280 (1-3) (2011) $244-251$.

19. D. Valero, J. M. Ortiz, V. García, E. Expósito, V. Montiel and A. Aldaz. Electrocoagulation of Wastewater from Almond Industry, Chemosphere, 84 (9) (2011) 1290-1295.

20. L. J. Xu, B. W. Sheldon, D. K. Larick and R. E. Carawan. Recovery and Utilization of Useful By-Products from Egg Processing Wastewater by Electrocoagulation, Poultry Sci, 81(6) (2002) 785-792.

21. S. Vasudevan, J. Lakshmi, J. Jayaraj and G. Sozhan. Remediation of phosphatecontaminated water by electrocoagulation with aluminium, aluminium alloy and mild steel anodes. J. Haz. Mat., 164 (2009) 1480-1486.

22. S. Vasudevan, F. Epron, J. Lakshmi, S. Ravichandran, S Mohan and G. Sozhan. Removal of $\mathrm{NO}_{3}{ }^{-}$from drinking water by electrocoagulation - An alternative approach. Clean Soil Air Water, 38 (2010) 225-229.

23. C. Delaire, C.M. Van Genuchten, K.L. Nelson, S.E. Amrose and A.J. Gadgil. Escherichia coli attenuation by Fe electrocoagulation in synthetic bengal Groundwater: Effect of pH and natural organic matter Env. Sci. Tech., 49 (2015) 9945-9953.

24. E. Nariyan, A. Aghababaei and M. Sillanpää. Removal of pharmaceutical from water with an electrocoagulation process; effect of various parameters and studies of isotherm and kinetic. Sep. Pur. Tech., 188 (2017) 266-281.

25. V. Wei, M. Elektorowicz and J.A. Oleszkiewicz. Influence of electric current on bacterial viability in wastewater treatment. Wat. Res., 45 (2011) 5058-5062.

26. H.J. Mansoorian, A.H. Mahvi and A.J. Jafari. Removal of lead and zinc from battery industry wastewater using electrocoagulation process: influence of direct and alternating current by using iron and stainless steel rod electrodes. Sep. Pur. Tech., 135 (2014) 165-175.

27. S. Vasudevan, J. Lakshmi and G. Sozhan. Electrochemically assisted coagulation for the removal of boron from water using zinc anode. Desalin., 310, (2013) 122-129. 
28. S. Vasudevan, J. Lakshmi and M. Packiyam. Electrocoagulation studies on removal of cadmium using magnesium electrode. J. Appl. Electrochem, 40 (2010) 2023 2032.

29. S. Zodi, B. Merzouk, O. Potier, F. Lapicque and J.-P. Leclerc. Direct Red 81 dye removal by a continuous flow electrocoagulation/flotation reactor. Sep. Pur. Tech., 108 (2013) 215-222.

30. B.K. Körbahti and A. Tanyolaç. Electrochemical treatment of simulated industrial paint wastewater in a continuous tubular reactor. Chem Eng J. 148(2) (2009) 444-451.

31. S. Vasudevan, B.S. Kannan, J. Lakshmi, S. Mohanraj and G. Sozhan. Effects of alternating and direct current in electrocoagulation process on the removal of fluoride from water, J. Chem Tech Biotech, 86 (2011) 428-43.

32. O. Sahu, B. Mazumdar and P.K. Chaudhari, Treatment of wastewater by electrocoagulation: a review, Env. Sci. Pollut Res., 21 (2014) 2397-2413.

33. M. Kobya, M. Bayramoglu and M. Eyvaz, Techno-economical evaluation of electrocoagulation for the textile wastewater using different electrode connections, J. Haz. Mat., 148 (2007) 311-318.

34. M. Kobya, F. Ulu, U. Gebologlu, E. Demirbas and M.S. Oncel, Treatment of potable water containing low concentration of arsenic with electrocoagulation: different connection modes and Fe-Al electrodes, Sep. Pur. Tech., 77 (2011) 283-293.

35. S. Garcia-Segura, M.M.S.G. Eiband, J.V. Melo and C.A. Martínez-Huitle, Electrocoagulation and advanced electrocoagulation processes: a general review about the fundamentals, emerging applications and its association with other technologies, J. Electroanal. Chem., 801 (2017) 267-299.

36. K. Rajaniemi, J.-P. Metsävainio and V. Kuokkanen. 2016. Apparatus and method for treatment of various types of water and wastewater based on electrocoagulation. FI20165317. https://fi.espacenet.com/publicationDetails/biblio? Il=0\&ND=3\&adjacent=true\&locale=fi FI\&FT=D\&date $=20171014 \& C C=F I \& N R=20165317 A \& K C=A \#$ (Accessed March 1, 2019).

37. M. Kobya, E. Demirbas, A. Dedeli and M.T. Sensoy. Treatment of rinse water from zinc phosphate coating by batch and continuous electrocoagulation processes. $\mathrm{J}$ Haz. Mat., 173 (2010) 326-334.

38. T.H. Kim, C. Park, E.B. Shin and S. Kim. Decolorization of disperse and reactive dyes by continuous electrocoagulation process. Desalin., 150 (2002) 165-175

39. L. Seng. 2007. Advanced electrocoagulation device and process of using the same for wastewater treatment. WO2007050041. https://fi.espacenet.com/publicationDetails/biblio?FT=D\&date=20070503\&DB=\&locale $=$ fi $\mathrm{FI} \& \mathrm{CC}=\mathrm{WO} \& N R=2007050041 \mathrm{~A} 1 \& \mathrm{KC}=\mathrm{A} 1 \& N D=4$. (Accessed March 1, 2019).

40. W. Gilmore. 2015. Electrocoagulation chamber with atmospheric and pressurized flow regimes. WO2015187511. https://fi.espacenet.com/publicationDetails/biblio?CC=WO\&NR=2015187511A1\&KC= A1\&FT=D\&ND=3\&date=20151210\&DB=\&locale=fi FI. (Accessed March 1, 2019).

41. M. Gyoergy, L. Zsoltne, K. Robert and C. Pal. 1993. Cross flow electrolytic cell, particularly for electroflocculation and/or electroflotation purification of emulsion and/or suspension sewage. HUT63119.

https://fi.espacenet.com/publicationDetails/biblio?!|=0\&ND=3\&adjacent=true\&locale=fi FI\&FT=D\&date $=19930728 \& C C=H U \& N R=T 63119 A \& K C=A$. (Accessed March 1, 2019).

42. D. Ghernaout, A. Badis, A. Kellil and B. Ghernaout. Application of electrocoagulation in Escherichia coli culture and two surface waters. Desalination, 219 (1-3) (2008) 118-125

43. J.N. Hakizimana, B. Gourich, C. Vial, P. Drogui, A. Oumani, J. Naja and L. Hilali. Assessment of hardness, microorganism and organic matter removal from seawater by electrocoagulation as a pretreatment of desalination by reverse osmosis. Desalination, 393 (2016) 90-101 
44. M.H. El-Masry, O.M. Sadek and W.K. Mekhemer. Purification of raw surface water using electro-coagulation method. Water Air Soil Pollut., 158 (2004) 373-385

45. M. Kobya, C. Ciftci, M. Bayramoglu and M. T. Sensoy. Study on the Treatment of Waste Metal Cutting Fluids Using Electrocoagulation. Sep. Pur. Tech, 60 (3) (2008) 285-291.

46. M. Asselin, P. Drogui, S. K. Brar, H. Benmoussa and J. Blais. Organics Removal in Oily Bilgewater by Electrocoagulation Process, J. Haz. Mat., 151(2-3) (2008) 446455.

47. J. P. Kushwaha, V. C. Srivastava and I. D. Mall. Organics Removal from Dairy Wastewater by Electrochemical Treatment and Residue Disposal. Sep. Pur. Tech., 76 (2) (2010) 198-205.

48. M. Kobya, H. Hiz, E. Senturk, C. Aydiner and E. Demirbas. Treatment of Potato Chips Manufacturing Wastewater by Electrocoagulation. Desalin., 190 (1-3) (2006) 201-211.

49. M. Asselin, P. Drogui, H. Benmoussa and J. Blais. Effectiveness of Electrocoagulation Process in Removing Organic Compounds from Slaughterhouse Wastewater Using Monopolar and Bipolar Electrolytic Cells. Chemosp, 72 (11) (2008) 1727-1733.

50. M. Kobya and S. Delipinar. Treatment of the Baker's Yeast Wastewater by Electrocoagulation. J. Haz. Mat., 154 (1-3) (2008) 1133- 1140.

51. M. Kobya, E. Demirbas, N. U. Parlak and S. Yigit. Treatment of Cadmium and Nickel Electroplating Rinse Water by Electrocoagulation. Env. Tech, 31 (13) (2010) 14711481.

52. M. Solak, M. Kılıç, Y. Hüseyin and A. Şencan. Removal of Suspended Solids and Turbidity from Marble Processing Wastewaters by Electrocoagulation: Comparison of Electrode Materials and Electrode Connection Systems. J. Haz. Mat., 172 (1) (2009) 345-352.

53. W. Wan, T. J. Pepping, T. Banerji, S. Chaudhari and D. E. Giammar. Effects of Water Chemistry on Arsenic Removal from Drinking Water by Electrocoagulation. Wat Res, 45 (1) (2011) 384-392.

54. M. Behbahani, M. R. A. Moghaddam and M. Arami. Techno-Economical Evaluation of Fluoride Removal by Electrocoagulation Process: Optimization through Response Surface Methodology. Desalin., 271 (1-3) (2011) 209-218.

55. M. Karhu, V. Kuokkanen, T. Kuokkanen and J. Ramo. Bench Scale Electrocoagulation Studies of Bio Oil-in-Water and Synthetic Oil-in-Water Emulsions. Sep. Pur. Tech., 96 (2012) 296-305.

56. B. Merzouk, B. Gourich, K. Madani, C. Vial and A. Sekki. Removal of a disperse red dye from synthetic wastewater by chemical coagulation and continuous electrocoagulation. A comparative study. Desalin, 272 (1) (2011) 246-253.

57. M. Kobya, E. Gengec and E. Demirbas. Operating parameters and costs assessments of a real dyehouse wastewater effluent treated by a continuous electrocoagulation process. Chem. Eng. Process. Process Intensif., 101 (2015) 87100.

58. M.M. Emamjomeh and M. Sivakumar. Fluoride removal by a continuous flow electrocoagulation reactor. J. Env. Manag., 90 (2009) 1204-1212.

59. E. Karamati-Niaragh, M.R.A. Moghaddam, M. Mahdi and E. Nazlabadi. Evaluation of direct and alternating current on nitrate removal using a continuous electrocoagulation process: Economical and environmental approaches through RSM. J. Env. Manag., 230 (2018) 245-254.

60. K. Hendaoui, F. Ayari, I.B. Rayana, R.B. Ammar, F. Darragi and M. Trabelsi-Ayadi. Real indigo dyeing effluent decontamination using continuous electrocoagulation cell: study and optimization using Response Surface Methodology. Process Saf. Env. Prot., 116 (2018) 578-589.

61. E. Demirbas and M. Kobya. Operating cost and treatment of metalworking fluid wastewater by chemical coagulation and electrocoagulation processes. Process. Saf. Env. Prot., 105 (2017) 79-90. 
